\title{
Stimulation of carp Cyprinus carpio lymphocytes in vitro by the blood fluke Sanguinicola inermis (Trematoda: Sanguinicolidae)
}

\author{
D. T. Richards ${ }^{1}$, D. Hoole ${ }^{1, *}$, J. W. Lewis ${ }^{2}$, E. Ewens ${ }^{2}$, C. Arme ${ }^{1}$ \\ 'Centre for Applied Entomology and Parasitology, Department of Biological Sciences, Keele University, Keele, \\ Staffordshire ST5 5BG, United Kingdom \\ ${ }^{2}$ School of Biological Sciences, Royal Holloway, University of London, Egham, Surrey TW20 0EX, United Kingdom
}

\begin{abstract}
Interactions between extracts of adults or cercariae of the pathogenic blood fluke Sanguinicola inermis and lymphocytes of carp Cyprinus carpio were investigated in vitro by monitonng proliferation of pronephric and splenic lymphocytes at 10 and $20^{\circ} \mathrm{C}$. Adult $S$. inermis were more mitogenic than cercariae at both temperatures. Splenic lymphocytes only responded to adult worm extracts at $10^{\circ} \mathrm{C}$, whilst pronephric lymphocytes responded in a dose-dependent way to all extracts except those of cercariae at $10^{\circ} \mathrm{C}$. Higher concentrations of the extracts reduced the degree of lymphocyte stimulation. These effects on pronephric and splenic lymphocytes of carp may be associated with stimulation and/or suppression of the immune response of the host.
\end{abstract}

KEY WORDS: Cyprinus carpio Sanguinicola inermis Lymphocyte - Mitogen

\section{INTRODUCTION}

Adult stages of the pathogenic fluke Sanguinicola inermis Plehn, 1905 inhabit the vascular system of carp Cyprinus carpio L. and shed eggs into the blood vessels (Lee 1990, Sommerville \& Iqbal 1991, Kirk \& Lewis 1993). Severe pathology has been associated with high intensities of adult parasites and, in particular, with eggs and migrating miracidia which become entrapped in host tissues and surrounded by inflammatory cells prior to encapsulation by collagen produced by fibroblasts (Lee 1990). Transmission electron microscopy has revealed that eggs less than 1 wk old were initially encapsulated by eosinophils, prior to infiltration of neutrophils and macrophages into the response around 1 to $2 \mathrm{wk}$ old eggs. Eggs 2 to $3 \mathrm{wk}$ of age were surrounded by several layers of macrophages, and the breakdown and destruction of the egg and enclosed miracidium occurred within a granulomatous lesion associated with eggs of 5 to 6 wk of age (Richards et al. 1994a).

'E-mail: bial0@cc.keele.ac.uk
Sanguinicola inermis infections also induce changes in the cellular composition of carp lymphoid organs (Richards et al. 1994b). The most marked of these changes was a significant reduction of erythrocytes in the spleen, which was attributed to parasite-induced haemorrhaging from capillaries. There were also significant increases of macrophages and neutrophils in the pronephros which correlated with the predominance of these cell types in the inflammatory response (Richards et al. 1994a). Richards et al. (1994b), however, found no evidence that lymphocyte numbers increased significantly in infected fish, although they postulated that lymphocytes may have increased in number relative to controls prior to $5 \mathrm{wk}$ after the initial infection, which was when their first cell counts were made.

Previous studies have demonstrated that fish lymphocytes can be induced to proliferate in vitro in response to the presence of $\mathrm{B}$-cell and $\mathrm{T}$-cell mitogens such as phytohaemagglutinin A (PHA), concanavalin A (ConA), lipopolysaccharide of Escherichia coli (LPS) and lectin of pokeweed, Phytolacca americana (PWM) (Etlinger et al. 1976, Cuchens \& Clem 1977, Liewes \& 
van Dam 1982, Liewes et al. 1982, Warr \& Simon 1983, Caspi et al. 1984, McKinney \& Schmale 1988. Tillitt et al. 1988, Estepa \& Coll 1992, Koumans-van Diepen et al. 1994) In addition, proliferation of lymphocytes isolated from fish lymphoid organs has been shown to be enhanced in the presence of extracts or antigens from bacteria such as Vibrio anguillarum (Yui \& Kaattari 1987) and Aeromonas salmonicida (Pourreau et al. 1987. Tatner 1990) and the plerocercoid stage of the cestode Ligula intestinalis (Taylor \& Hoole 1994).

The aim of this study was to determine whether extracts of adult and cercarial stages of Sanguinicola inermis induced proliferation of pronephric and splenic lymphocytes of carp. The results obtained were compared with those produced by mitogens known to stimulate manmalian B-iymphocytes andior $\mathrm{I}$ lymphocytes.

\section{METHODS}

Collection of parasite material. The snails Lymnaed peregra and $L$. auricularia were obtained from the margins of a lake in the West Midlands and screened for cercarial infections (Richards et al. 1994a). Sanguinicola inermis cercariae shed from these snails were used to prepare cercarial extracts or to infect carp and provide a source of adult flukes.

Carp, aged 3 to 4 mo, were obtained from a Sanguinicola inermis-free commercial fishery and exposed to $500 \mathrm{~S}$. inermis cercariae (Kirk \& Lewis 1992, Richards et al. 1994a). Carp were maintained at $20^{\circ} \mathrm{C}$ and adult flukes were recovered from the heart and associated vasculature from 3 to $5 \mathrm{wk}$ post-infection (p. i.).

Preparation of parasite extracts. Extracts of up to 450 adults and 25000 cercariae were prepared in ultrapure water by freeze-thawing each parasite suspension 5 times, sonicating on ice for $60 \mathrm{~s}$, centrifuging at $16500 \times g$ at $4^{\circ} \mathrm{C}$ for $30 \mathrm{~min}$ to remove particulate matter and filter-sterilising the supernatant using $0.22 \mu \mathrm{m}$ sterile filters. The protein concentration of each filtered supernatant was then determined using a Bicinchoninic acid assay kit (Pierce) The adult and cercarial extracts were diluted in sterile Leibovitz (L-15) culture medium supplemented with $5 \%$ heat-inactivated $\left(20 \mathrm{~min}\right.$ at $\left.60^{\circ} \mathrm{C}\right)$ foetal calf serum (FCS), penicillin (100 $\mathrm{IU} \mathrm{m \textrm {m } ^ { - 1 }}$ ), streptomycin $\left(100 \mu \mathrm{g} \mathrm{ml}^{-1}\right)$, heparin (5 IU ml-1) and L-glutamine (2 $\mathrm{mM}$ ).

Mitogen preparations. Four mitogens, namely PHA (Sigma: Lot no. 92H95651), ConA Type IV-S (Sigma: Lot no. 83H9404), LPS of Escherichia coli: Serotype 055:B5 (Sigma: Lot no. 122H4025) and PWM (Sigma: Lot no. 53H9576) were prepared at 12 concentrations ranging from 0.975 to $1000 \mu \mathrm{g} \mathrm{ml}^{-1}$ in supplemented $\mathrm{L}$ 15 medium under sterile conditions.
Carp cell isolation. As found by other workers (e.g. Liewes \& van Dam 1982, Liewes et al. 1982), attempts to isolate lymphocytes from carp organs gave inconsistent results, so the experiments were undertaken using mixed leucocyte suspensions.

Uninfected carp were bled by caudal puncture prior to removing the pronephros and spleen under sterile conditions. Each tissue was dissociated through a sterile stainless steel mesh (pore size $0.3 \mathrm{~mm}^{2}$ ) into $1.2 \mathrm{ml}$ of supplemented L-15 medium. The viability of cells in each suspension was tested by $0.4 \% \mathrm{w} / \mathrm{v}$ Trypan Blue exclusion throughout the experimental procedures. Cell counts were determined and fresh supplemented L-15 medium added to adjust the cell concentrations to $2.5 \times 10^{6}$ lymphocytes $\mathrm{ml}^{-1}$. Cells were incubated at either 10 or $20^{\circ} \mathrm{C}$ for at least $1 \mathrm{~h}$ prior to the respective assays.

Proliferation assays. $100 \mu \mathrm{l}$ of supplemented L-15 medium containing $2.5 \times 10^{5}$ splenic or pronephric lymphocytes from individual fish was added to wells of a 96 -well plate. $100 \mu \mathrm{l}$ of the respective mitogen or parasite extract suspension was then added to each well. In control wells, mitogen or parasite suspensions were replaced with $100 \mu \mathrm{l}$ of supplemented L-15 medium. Plates were incubated in a humidified atmosphere at either 10 or $20^{\circ} \mathrm{C}$ for $72 \mathrm{~h}$ before addition of $0.5 \mu \mathrm{Ci}$ [C6- ${ }^{3} \mathrm{H}$ ]thymidine (Amersham: Lot no. B337) in $20 \mu \mathrm{l}$ supplemented L-15 medium. After a further $24 \mathrm{~h}$ incubation, cells were harvested using a Titerex Cell Harvester (Flow Laboratories) by water lysis onto glass fibre filter paper (Flow Laboratories). Filter papers were transferred to scintillation vials (LIP), $4 \mathrm{ml}$ of Ecoscint A scintillation fluid (National Diagnostics) was added and counts per minute (cpm) were recorded on a LKB Wallac 1219 Rackbeta Liquid Scintillation Counter.

Initial experiments were carried out at $20^{\circ} \mathrm{C}$ to determine the responsiveness of carp pronephric and splenic lymphocytes to the 4 mitogens at concentrations ranging from 0.48 to $500 \mu \mathrm{g} \mathrm{ml}^{-1}$

Proliferation of lymphocytes from 4 uninfected carp was then compared at both $10^{\circ} \mathrm{C}$ and $20^{\circ} \mathrm{C}$ in the presence of extracts of Sanguinicola inermis adults or cercariae and the optimum concentrations of PHA, ConA, LPS and PWM. Statistical analyses were carried out on the original cpm data using Student's t-test.

\section{RESULTS}

The ability of each mitogen or parasite extract to stimulate lymphocyte proliferation was considered in terms of its Stimulation Index (SI), where:

$$
\mathrm{SI}=\frac{\mathrm{cpm} \text { cells stimulated by parasite extract or mitogen }}{\mathrm{cpm} \text { unstimulated control cells }}
$$




\section{Mitogen-induced stimulation of lymphocytes}

Pronephric and splenic lymphocytes responded to both B-cell and T-cell mitogens. The highest mean SI values for pronephric lymphocytes were obtained with concentrations of PHA at $3.9 \mu \mathrm{g} \mathrm{m} \mathrm{ml}^{-1}$, LPS at $62.5 \mu \mathrm{g}$ $\mathrm{ml}^{-1}$ and both. ConA and PWM at $0.45 \mu \mathrm{g} \mathrm{ml^{-1 }}$ The highest mean SI for splenic lymphocytes were obtained with concentrations of PHA, ConA, LPS and PWM at $0.95 \mu \mathrm{g} \mathrm{ml} \mathrm{m}^{-1}$. These mitogen concentrations were used in a subsequent experiment to compare mitogen SI with those SI produced by parasite extracts.

\section{Lymphocyte stimulation by parasite extracts}

The results indicate that Sanguinicola inermis extracts induced a differential lymphocyte proliferation response that was dependent on parasite stage, incubation temperature and the host lymphoid organ from which the cells were isolated.
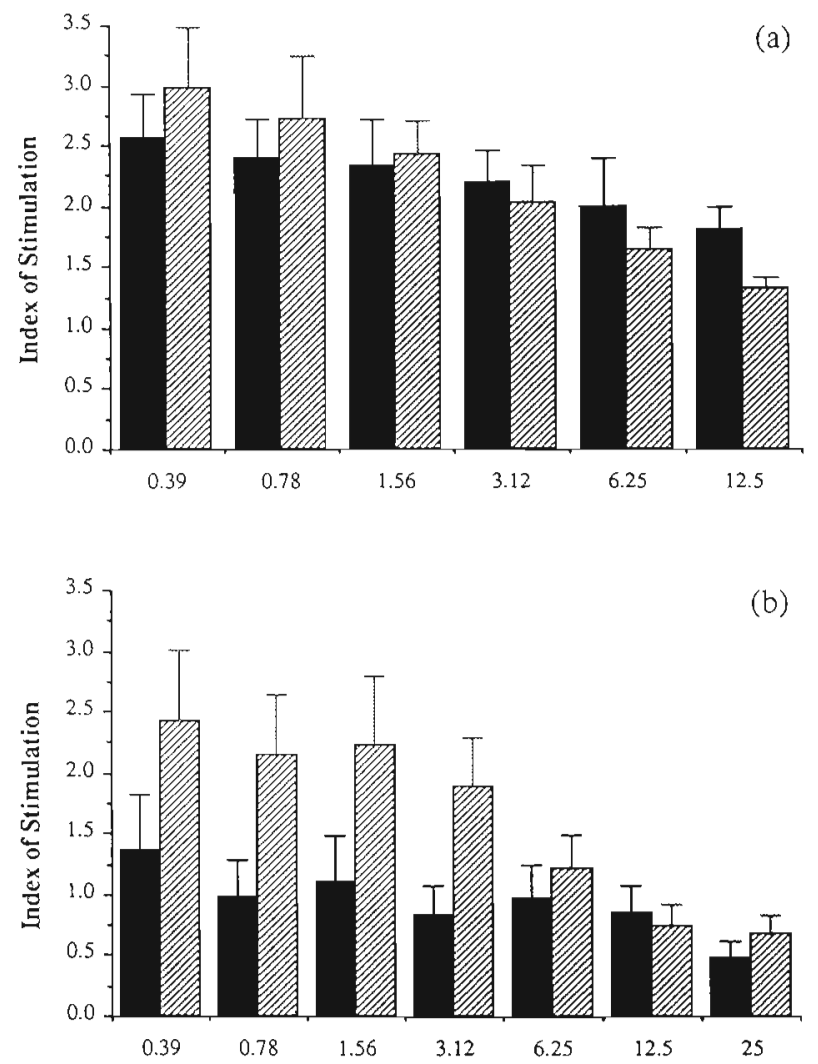

Protein Concentration $(\mu \mathrm{g} / \mathrm{ml})$

Fig. 1. Proliferation of pronephric lymphocytes of carp Cyprinus carpio in the presence of whole extracts of Sanguinicola inermis (a) adults and (b) cercariae at (a) $10^{\circ} \mathrm{C}$ and ( $20^{\circ} \mathrm{C}$. Means + SEM
Extracts of adult Sanguinicola inermis were more mitogenic than those of cercariae to pronephric lymphocytes at $20^{\circ} \mathrm{C}$ (Fig. $1 ; t=2.31, \mathrm{p}<0.05$ ) and $10^{\circ} \mathrm{C}$ (Fig. $1_{i} t=3.38, \mathrm{p}<0.01$ ) and to splenic lymphocytes at $20^{\circ} \mathrm{C}$ (Fig. $2 ; t=3.88, \mathrm{p}<0.01$ ) and $10^{\circ} \mathrm{C}$ (Fig. $2 ; t=3.30$, $\mathrm{p}<0.01$ )

Adult worm extracts were more mitogenic at $20^{\circ} \mathrm{C}$ than at $10^{\circ} \mathrm{C}$ to pronephric lymphocytes (Fig. $1 \mathrm{a}_{;} t=$ 7.26, $\mathrm{p}<0.001$ ), but significantly less mitogenic at $20^{\circ} \mathrm{C}$ to splenic lymphocytes (Fig. 2a; $t=8.76, p<$ 0.001 ). In contrast, cercarial extracts were more mitogenic at $20^{\circ} \mathrm{C}$ than at $10^{\circ} \mathrm{C}$ to both pronephric lymphocytes (Fig. $1 b_{;} t=11.39, p<0.001$ ) and splenic lymphocytes (Fig. 2b; $t=15.12, p<0.001$ ).

Adult worm extracts were more mitogenic to pronephric lymphocytes than splenic lymphocytes at $20^{\circ} \mathrm{C}(t=4.46, \mathrm{p}<0.001)$, but not at $10^{\circ} \mathrm{C}(t=1.86$, $\mathrm{p}>0.05)$. Cercarial extracts were more mitogenic to pronephric lymphocytes than splenic lymphocytes at both $20^{\circ} \mathrm{C}(t=5.10, \mathrm{p}<0.001)$ and $10^{\circ} \mathrm{C}(t=6.55, \mathrm{p}<$ $0.001)$
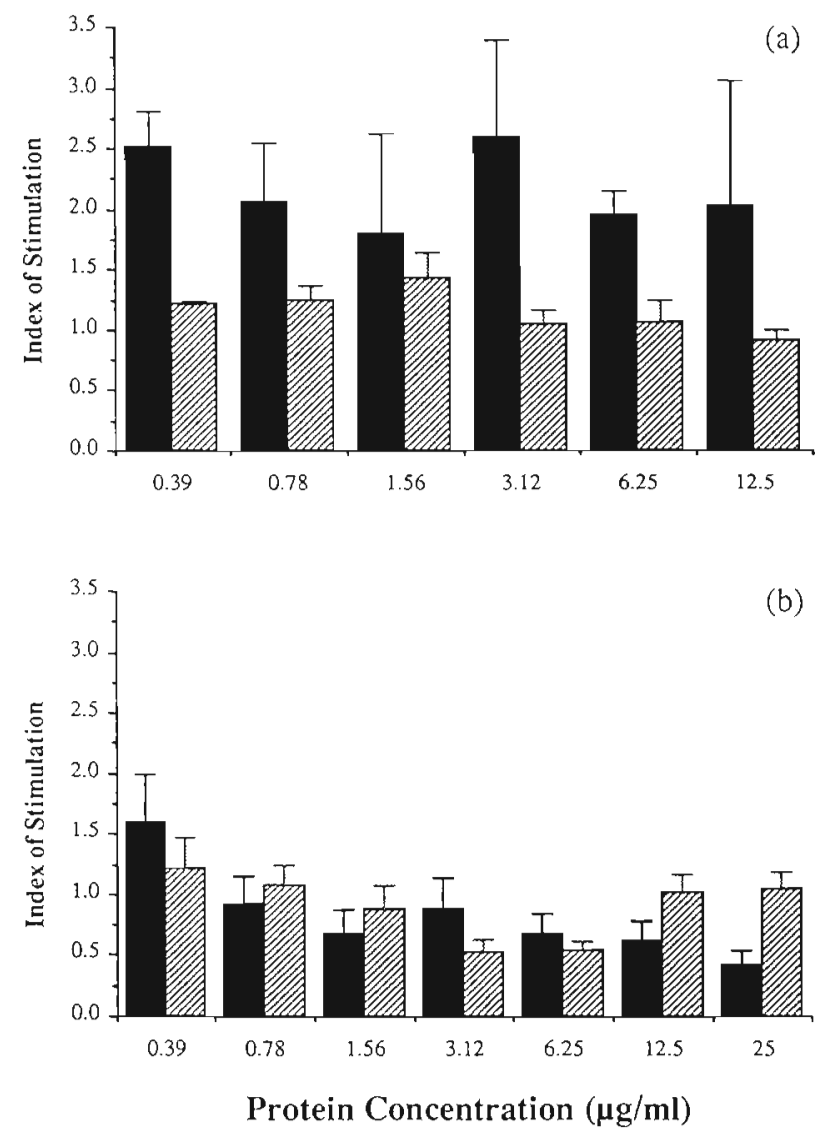

Fig. 2. Proliferation of splenic lymphocytes of carp Cyprinus carpio in the presence of whole extracts of Sanguinicola inermis (a) adults and (b) cercariae at (- $10^{\circ} \mathrm{C}$ and (ø) $20^{\circ} \mathrm{C}$. Means + SEM 

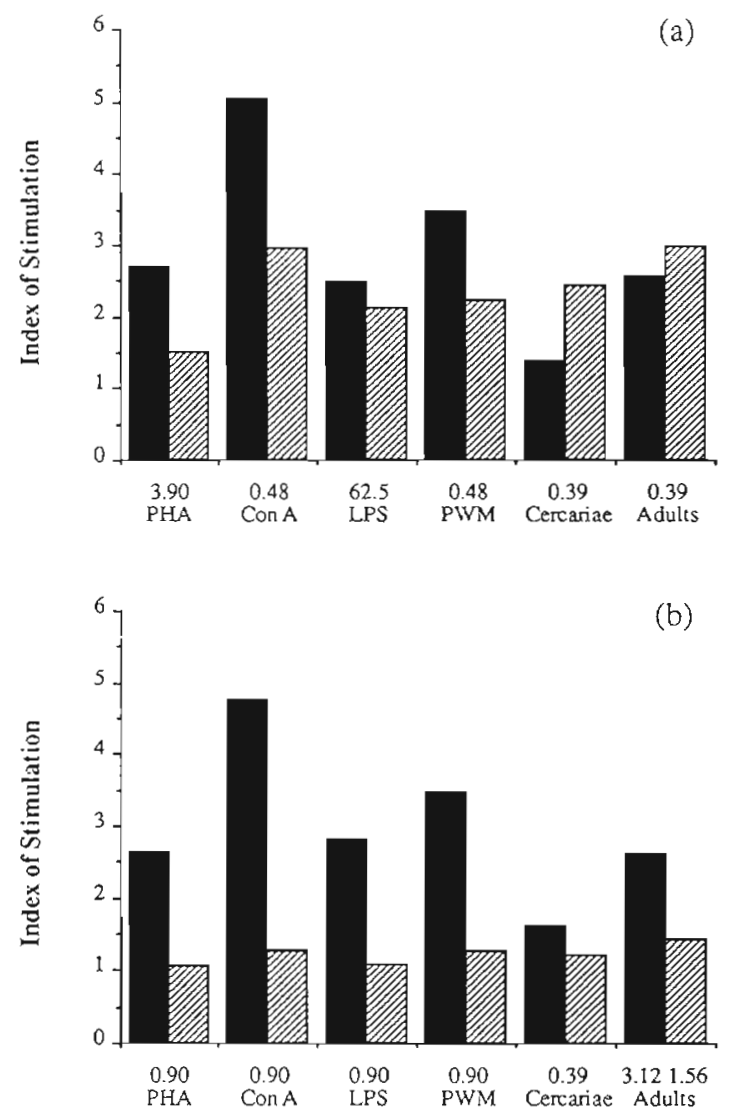

Concentration $(\mu \mathrm{g} / \mathrm{ml})$

Fig. 3. Comparison between the highest levels of proliferation of (a) pronephric and (b) splenic lymphocytes of carp Cyprinus carpio, in the presence of the mitogens PHA, ConA, LPS and PWM, and whole extracts of cercariae or adults of Sanguinicola inermis at $10^{\circ} \mathrm{C}$ and $20^{\circ} \mathrm{C}$

Pronephric lymphocytes responded to Sanguinicola inermis adult and cercarial extracts in a dose-dependent way: higher concentrations of extracts reduced the degree of iymphocyte stimulation (Fig. 1). Splenic lymphocytes only responded to $S$. inermis adult worm extracts at $10^{\circ} \mathrm{C}$ (Fig. 2).

The highest mean SI values abtained for pronephric and splenic lymphocytes in the presence of adult and cercarial extracts were found to be comparable with those produced by the B-cell and T-cell mitogens (Fig. 3)

\section{DISCUSSION}

It has previously been established that carp elicit a cellular immune response against the eggs of Sanquinicola inermis which comprises eosinophils, neutrophils and macrophages (Richards et al. 1994a). The present study has demonstrated that extracts of both adult and cercarial stages of the parasite can also stimulate the proliferation of carp lymphocytes in vitro, in a dose-dependent manner. Previous observations have revealed that these blastogenic responses can be induced in mammalian lymphocytes in vitro by substances produced by other helminths such as the cestodes Echinococcus granulosus (Dixon et al. 1978) and Taenia multiceps (Rakha et al. 1991) and in pronephric lymphocytes of roach Rutilus rutilus by extracts of Ligula intestinalis (Taylor \& Hoole 1994).

In the present study, marked differences were observed between the proliferative responses of carp lymphocytes that were related to the temperature at which the cells were incubated, the host organ from which they were isolated and the stage of the parasite to which they were exposed. The degree of stimulation was found to be comparable with levels produced by known T-cell and B-cell mitogens, although the possible antigen(s), either excretory-secretory or somatic, responsible for inducing the proliferative responses of lymphocytes from the pronephros and spleen, and their concentrations in the extracts are not known. The concentrations of parasite antigens that induced the proliferative responses may, therefore, have been much lower than those of the mitogens. In addition, it should be noted that antigens inducing the proliferation responses may not have been present at the same concentrations in adult and cercarial worm extracts and that the mechanisms of lymphocyte activation differ for mitogens and antigens.

Lymphocyte proliferation was found to be enhanced in response to both adult and cercarial extracts at $20^{\circ} \mathrm{C}$, when compared with those at $10^{\circ} \mathrm{C}$, and adult flukes were significantly more mitogenic than cercariae at both temperatures. This temperature-dependent effect may play an important role in this host-parasite interaction and could be related to the development and rate of maturation of adult Sanguinicola inermis. Adults can overwinter in infected carp in natural systems at relatively low temperatures (Lee 1990), whereas they mature after 2 to 3 mo in carp maintained at 15 to $18^{\circ} \mathrm{C}$ (Sommerville \& Iqbal 1991) and in less than 1 mo in carp maintained at $20^{\circ} \mathrm{C}$ (Kirk \& Lewis 1992). At this latter temperature, numbers of adult flukes peak around $30 \mathrm{~d}$ p.i. and the adults may only survive for up to $8 \mathrm{wk}$ p.i. (Lee 1990). A reduction in the efficiency of the immune response at lower temperatures may explain the ability of adult $S$. inermis to survive in carp for relatively long periods over winter. The effects of this temperature-dependence may subsequently be reversed during the summer months as water temperatures rise to levels that enhance antibody production.

Temperature has previously been shown to play an important role in the effective functioning of the 
immune response of fish (Avtalion et al. 1980, Rijkers et al. 1980, 1981, Clem et al. 1984). For example, Rijkers et al. $(1980,1981)$ found that numbers of primary antibody-producing plaque-forming cells (PFC) in carp maintained at $24^{\circ} \mathrm{C}$ peaked $9 \mathrm{~d}$ after injection with sheep red blood cells (SRBC), compared with an equivalent peak at $49 \mathrm{~d}$ post-injection in fish kept at $12^{\circ} \mathrm{C}$. Similarly, Wishkovsky \& Avtalion (1987) found a typical primary antibody response after injecting carp maintained at $25^{\circ} \mathrm{C}$ with formalin-killed Vibrio anguillarum, but not in fish injected with the same antigen and held at $12^{\circ} \mathrm{C}$. It has been suggested from studies on mitogen-induced proliferation of fish leucocytes that temperature-related differences in antibody responses result from a reduced ability of helper cells to process antigens at lower temperatures rather than an inability of antibody-producing cells to produce antibody (Avtalion et al. 1976, Cuchens \& Clem 1977, Liewes et al. 1982), or because accessory or antigen presenting cell.s such as monocytes and macrophages function less efficiently (Vallejo et al. 1992).

Whether this is the case in Sanguinicola inermis infections is not known. However, the reduced ability of carp lymphocytes to proliferate in response to $S$. inermis extracts at the lower temperature may suggest that the immune system is impaired. This may be an advantage to the parasite, particularly during the spring and autumn months, when peaks in cercarial release from Lymnaea spp. snails occur (Lee 1990) and water temperatures are lower. The vulnerable stages of the parasite occur during penetration and migration through the skin, subcutaneous tissues and vascular system at a time of reduced immune capability. Parasite survival may be enhanced by avoiding the immune responses. The host may, however, still be capable of responding to the presence of the parasite by utilising non-specific cellular responses. This has previously been found in studies on carp lymphoid organs that noted higher numbers of granulocytes in fish maintained at lower temperatures, which suggested that non-lymphoid defence may play a more important role when circumstances are less favourable for the formation of antibodies (Rijkers et al. 1981).

The fact remains, however, that Sanguinicola iner$m$ is can survive and reproduce effectively in carp over a wide range of environmental temperatures. Therefore, even if, as suggested, the humoral immune response is initiated against $S$. inermis, the parasite may have one, or more, as yet unknown mechanisms of evading the antibody responses. M. Roberts \& D. Hoole (unpubl. data) have found that host molecules occur on the surface of adult $S$. inermis, but the nature of these molecules has not yet been determined. $S$. inermis may, therefore, be able to acquire host molecules and express them on its surface. This evasion strategy has previously been demonstrated by mammalian schistosomes (Capron \& Camus 1979). Another evasion strategy used by parasites is the production of cytotoxic substances such as proteinase inhibitors, which suppress the effective functioning of the host immune system, and thus enhance parasite survival (Capron \& Camus 1979, Hoole \& Arme 1.982, 1983, Pourreau et al. 1987. Taylor \& Hoole 1989). Previous studies by Richards et al. (1994a) also found lysis of host cells around the eggs of $S$. inermis, but it is not known if this lysis occurred as a consequence of substances released from the entrapped eggs, which were subsequently encapsulated within a granulomatous lesion.

The present study demonstrated that at $20^{\circ} \mathrm{C}$, most proliferation occurred in pronephric lymphocytes, with relatively little response being induced in splenic cells. At $10^{\circ} \mathrm{C}$, however, lymphocytes from both the spleen and pronephros were stimulated, but to a significantly lesser degree than those of the pronephros at $20^{\circ} \mathrm{C}$. Previous observations on changes in the cellular composition of the lymphoid organs of Sanguinicola inermis-infected carp maintained at $20^{\circ} \mathrm{C}$ have found relatively few changes in the leucocyte composition of the spleen, whereas in the pronephros there were marked and significant increases of leucocytes, particularly neutrophils (Richards et al. 1994b). Because the response of the pronephros was significantly greater than that of the spleen to both adult and cercarial extracts, particularly at $20^{\circ} \mathrm{C}$, it is likely that the pronephros is more important in the immune response at higher temperatures, whilst the spleen, which responds to adult flukes at $10^{\circ} \mathrm{C}$, may be of greater importance at lower temperatures.

The differential effect of Sanguinicola inermis extracts on the stimulation of lymphocytes isolated from the spleen and pronephros may reflect the heterogeneity of the respective lymphocyte populations. It seems likely, from studies on the ultrastructure and mitogen responses of carp lymphocytes, that at least 2 distinct subpopulations exist that respond differentially to the T-cell mitogens PHA and ConA and the Bcell mitogen LPS (Caspi et al. 1984). Furthermore, Koumans-van Diepen et al. (1994), using immunocytochemical techniques and monoclonal antibodies to identify lymphocytes isolated from carp blood, concluded that LPS stimulates surface immunoglobulin positive cells and PHA stimulates surface immunoglobulin negative cells. However, these 2 lymphocyte subpopulations are unlikely to be equally divided between the pronephros and spleen. Rijkers et al. (1980) found that $90 \%$ of the antibody-producing PFC against SRBC in carp were found in the pronephros and mesonephros, with only low numbers found in the spleen. Also, Liewes et al. (1982) found that both splenic and pronephric leucocytes of carp responded to 
the T-cell mitogen PHA, and at very low levels to ConA, spleen leucocytes responded best to PWM but the B-cell mitogen LPS produced little stimulation.

The results of the present study may indicate that Sanguinicola inermis extracts are differentially stimulating the lymphocyte populations of the pronephros and spleen. It is suggested that at higher temperatures which prevail during the summer months, humoral immune responses, possibly mediated by pronephric lymphocytes, may be more important in the host response, whereas at lower temperatures non-specific responses, possibly mediated by $\mathrm{T}$-cells in the spleen, may predominate.

Richards et al. (1994b) found no increases in numbers of lymphocytes in the spleen and pronephros of infected calp ai 5 and 9 wk p.i., but the present study indicated that Sanguinicola inermis can induce differential lymphocyte proliferation. It is still unclear whether or not the parasite induces an antigen-specific antibody response. Further investigations are required to determine if $S$. inermis is stimulating $\mathrm{B}$-cells and/or helper T-cells, or whether stimulation is of cytotoxic Tcells, or others that mediate in the cellular response by directly stimulating eosinophils, neutrophils and macrophages.

Acknowledgement. This study was funded by the A.F.R.C. (Grant Number AG111/622).

\section{LITERATURE CITED}

Avtalion RR, Weiss E. Moalem T (1976) Regulatory effects of temperature upon immunity in ectothermic vertebrates. In: Marchalonis J (ed) Comparative immunology. Wiley, New York, p 227-238

Avtalion RR, Wishkovsky A, Katz D (1980) Regulatory effect of temperature on specific suppression and enhancement of the humoral response in fish. In: Manning MJ (ed) Phylogeny of immunological memory. Elsevier/North-Holland Biomedical Press, Amsterdam, p 113-121

Capron A, Camus D (1979) Immunoregulation by parasite extracts. Springer Semin Immunopathol 2:69-77

Caspi RR, Shahrabani R, Kehati-dan T, Avtalion RR (1984) Heterogenerty of mitogen-responsive lymphocytes in carp (Cyprinus carpio). Dev Comp Immunol 8:61-70

Clem LW, Faulmann E, Miller NW, Ellasaesser C, Lobb FJ, Cuchens MA (1984) Temperature-mediated processes in teleost immunity: differential effects on in vitro and in vivo temperatures on mitogenic responses of channel catfish lymphocytes. Dev Comp Immunol 8:313-322

Cuchens MA, Clem LW (1977) Phylogeny of lymphocyte heterogeneity II. Differential. effects of temperature on fish T-like and B-like cells. Cell Immunol 34:219-230

Dixon JB, Jenkins P, Allan D (1978) Blastic stimulation of unprimed mouse lymphocytes by living protoscolices of Echinococcus granulosus: a possible connection with transplant immunity. J Parasitol 64:949-950

Estepa A. Coll JM (1992) Mitogen-induced proliferation of trout kidney leucocytes by one-step culture in fibrin clots. Vet Immunol Immunopathol 32:165-177
Etlinger HM, Hodgins HO, Chiller JM (1976) Evolution of the lymphoid system. I. Evidence for lymphocyte heterogeneity in rainbow trout revealed by the organ distribution of mitogenic responses. J Immunol 116:1547=1.553

Hoole D. Arme C (1982) Ultrastructural studies on the cellular response of roach, Rutilus rutilus L., to the plerocercoid larva of the pseudophyllidean cestode, Ligula intestinalis. $J$ Fish Dis 5:131-144

Hoole D, Arme C (1983) Ultrastructural studies on the cellular response of fish hosts following experimental infection with the plerocercoid of Ligula intestinalis (Cestoda: Pseudophyllidea). Parasitology 87:139-149

Kirk RS, Lewis JW (1992) The laboratory maintenance of Sanguinicola inermis Plehn, 1905 (Digenea: Sanguinicolidae). Parasitology 104:121-127

Kirk RS, Lewis JW (1993) The life-cycle and morphology of Sanguinicola inermis Plehn, 1905 (Digenea: Sanguinicolidae). Syst Parasitol 25:125-133

Koumans-van Diepen JCE, Hamimen EGM, Rombout JHWM (1994) Immunocytochemical analysis of mitogen responses of carp (Cyprinus carpio L.) peripheral blood leucocytes. Vet Immunol Immunopathol 42:209-219

Lee RS (1990) The development of Sanguinicola inermis Plehn, 1905 (Digenea: Sanguinicolidae) in the common carp Cyprinus carpio L. PhD thesis, Royal Holloway \& Bedford New College, University of London

Liewes EW, van Dam R.H (1982) Procedures and application of the in vitro fish leukocyte stimulation assay. Dev Comp Immunol Suppl 2:223-232

Liewes EW, van Dam RH, Vos-Maas MG, Bootsma R (1982) Optimisation and kinetics of in vitro stimulation of carp (Cypnnus carpio L.) leukocytes. Vet Immunol Immunopathol 3:325-343

McKinney EC, Schmale MC (1988) Proliferative and cytotoxic responses of healthy bicolor damselfish. Dev Comp Immunol 12:207-212

Pourreau CN, Koopman MBH, Hendriks GFR, Evenberg D, van Muswinkel WB (1987) Modulation of the mitogenic PHA response of carp, Cyprinus carpio L., by extracellular products of Aeromonas salmonicida. J Fish Biol 31 (Suppl A): 133-143

Rakha NK, Dixon JB, Skerritt GC, Carter SD, Jenkins P, Marshall-Clark S (1991) Lymphoreticular responses to metacestodes: Taenia multiceps (Cestoda) can modify interactions between accessory cells and responder cells during lymphocyte activation. Parasitology 102:133-140

Richards DT, Hoole D, Lewis JW, Ewens E, Arme C (1994a) Ultrastructural observations on the cellular response of carp (Cyprinus carpio L.) to eggs of the blood fluke Sanguinicola inermis Plehn, 1905 (Trematoda: Sanguinicoli. dae). J Fish Dis 17:439-446

Richards DT, Hoole D, Lewis JW, Ewens E, Arme C (1994b) Changes in the cellular composition of the spleen and pronephros of carp Cyprinus carpio infected with the blood fluke Sanguinicola inermis (Trematoda: Sanguinicolidae). Dis Aquat Org 19:173-179

Rijkers GT, Frederix-Wolters EMI I, van Muiswinkel WB (1980) The immune system of cyprinid fish. Kinetics and temperature dependence of antibody-producing cells in carp (Cyprinus carpio). Immunology 41:91-97

Rijkers GT. Wiegerinck JAM, van Oosterom R, van Muiswinkel WB (1981) Temperature dependence of humoral immunity in carp (Cyprinus carpio). In: Solomon JB (ed) Aspects of developmental and comparative immunology. Pergamon, Oxford, p 477-482

Sommerville C, Iqbal NAM (1991) The process of infection, migration, growth and development of Sanguinicola iner- 
mis Plehn, 1905 (Digenea: Sanguinicolidae) in carp, Cyprinus carpio L. J Fish Dis 14:211-219

Tatner MF (1990) Antigen-induced blastogenesis of salmon, Salmo salar L., head kidney leucocytes to modified Aeromonas salmonicida antıgens: a preliminary cvuluation method for potential vaccine antigens. J Fish Biol 36: $731-739$

Taylor MJ, Hoole D (1989) Ligula intestinalls (L.) (Cestoda: Pseudophyllidea): plerocercoid-induced changes in the spleen and pronephros of roach, Rutilus rutilus (L.), and gudgeon, Gobio gobio (L.). J Fish Biol 34:583-596

Taylor MJ, Hoole D (1994) Modulation of fish lymphocyte proliferation by extracts and isolated proteinase inhibitors of Ligula intestinalis (Cestoda). Fish Shellfish Immunol $4: 221-230$

Responsible Subject Editor: W. Körting. Hannover, Germany
Tillitt DE, Giesy JP, Fromm PO (1988) In vitro mitogenesis of peripheral blood lymphocytes from rainbow trout (Salmo gairdneri). Comp Biochem Physiol 89A:25-35

Vallejo AN, Miller NW, (lem LW (1992) Antıgen processing and presentation in teleost immune responses. A Rov Fish Dis 2:73-89

Warr GW, Simon RC (1983) The mitogen response potential of lymphocytes from the rainbow trout (Salmo gardneri) re-examined. Dev Comp Immunol 7:379-384

Wishkovsky A, Avtalion RR (1987) Induction of immunosuppression to bacterial antigens in carp. Cyprinus carpio. J Fish Biol 31 (Suppl A):101-106

Yui MA, Kaattari SL (1987) Vibrio anguillarum antigen stimulates mitogenesis and polyclonal activation of salmonid lymphocytes. Dev Comp Immunol 11:539-549

Manuscript first received: May 19, 1995

Revised version accepted: November 25, 1995 